\title{
Faktor Faktor yang Berhubungan dengan Kadar Hemoglobin pada Ibu Hamil di Wilayah Kerja Puskesmas Mopuya
}

\author{
${ }^{1}$ I Gusti Dwipayana Sanjaya \\ ${ }^{2}$ Nelly Mayulu \\ ${ }^{3}$ Shirly E. S. Kawengian
}

\author{
${ }^{1}$ Program Studi Pendidikan Dokter Fakultas Kedokteran Universitas Sam Ratulangi Manado \\ ${ }^{2}$ Bagian Ilmu Kesehatan Gizi Fakultas Kedokteran Universitas Sam Ratulangi Manado \\ Email: gustisanjaya92@gmail.com
}

\begin{abstract}
Abtract: Iron deficiency anemia remains as a public health problem with respect to its high prevalence and impact on maternal and infant health. This type of anemia often occurs because in pregnant women there is an increase in iron demand doubled due to increased plasma volume. This study was aimed to determine the relationship between hemoglobin level and maternal age, gestational age, parity, gestational distance, MUAC size, mother jobs, mother education, family income, and eating patterns. This was an analytical descriptive study with a cross-sectional design conducted at Mopuya Community Health Center, Bolaang Mongondow. Total respondents were 66 pregnant women obtained by using total sampling method. The relationship of hemoglobin level and the variables obtained the $P$-values as follows: 0.000 for mother age; 0,000 for pregnancy age; 0.000 for parity; 0.01 for pregnancy distance; 0.01 for MUAC; 0.01 for job status; 0.000 for mother education; 0.000 for family income; 0.000 for nuts diet; 0.000 for meat diet; 0.87 for fish diet; 0.000 for egg diet; all $P$ values were less than $\alpha=0.05$, except fish diet that had a $P$-value higher than $\alpha=0.05$. Conclusion: There were significant relationships between hemoglobin level and maternal age, gestational age, parity, pregnancy distance, LILA size, mother job, mother education, family income, as well as consumption pattern of eating nuts, meat, and eggs. However, there was no relationship between hemoglobin level and fish diet.
\end{abstract}

Keywords: hemoglobin, anemia, pregnant mother

\begin{abstract}
Abstrak: Anemia defisiensi besi masih menjadi masalah kesehatan masyarakat sehubungan dengan prevalensinya yang tinggi dan dampak kesehatan terhadap ibu dan bayinya. Anemia jenis tersebut sering terjadi karena pada ibu hamil terjadi peningkatan kebutuhan zat besi dua kali lipat akibat peningkatan volume plasma. Penelitian ini bertujuan untuk mengetahui adanya hubungan antara usia ibu hamil, usia kehamilan, paritas, jarak kehamilan, ukuran LILA, status pekerjaan ibu, pendidikan ibu, pendapatan keluarga, dan pola konsumsi makan dengan kadar hemoglobin $(\mathrm{Hb})$. Jenis penelitian ialah analitik deskriptif dengan desain potong lintang, yang dilakukan di Puskesmas Mopuya Kecamatan Bolaang Mongondow. Terdapat total 66 responden, diperoleh dengan metode total sampling. Hasil penelitian mendapatkan nilai $P$ sebagai berikut: 0,000 untuk usia ibu; 0,000 usia kehamilan; 0,000 paritas; 0,01 jarak kehamilan; 0,01 LILA; 0,00 status pekerjaan; 0,000 pendidikan; 0,000 pendapatan; 0,000 pola makan kacang-kacangan; 0,000 pola makan daging; 0,87 pola makan ikan; 0,000 pola makan telur; kesemuanya lebih kecil dibandingkan $\alpha=0,05$ kecuali untuk pola makan ikan dengan nilai $P$ lebih besar $\alpha=0,05$. Simpulan: Terdapat hubungan bermakna antara kadar hemoglobin $(\mathrm{Hb})$ dengan usia ibu, usia kehamilan, paritas, jarak kehamilan, ukuran LILA, status pekerjaan, pendidikan ibu, pendapatan keluarga, pola konsumsi makan kacang-kacangan, daging dan telur. Tidak terdapat hubungan antara kadar hemoglobin dengan pola makan ikan.
\end{abstract}

Kata kunci: kadar hemoglobin ( $\mathrm{Hb})$, anemia, ibu hamil 
Telah sekian tahun Maternal and Child Nutrition Study Group melakukan penelitian tentang maternal and child nutrition dengan komitmen mengurangi malnutrisi secara global dan nasional fokus untuk 1000 hari pertama kehidupan di negaranegara berpenghasilan rendah dan menengah namun peningkatan masih meninggalkan agenda yang tidak terselesaikan. ${ }^{1}$

Anemia defisiensi besi (ADB) masih menjadi masalah kesehatan masyarakat sehubungan dengan prevalensinya yang tinggi dan dampaknya terhadap kesehatan ibu beserta banyinya. Prevalensi ADB yang tinggi menyerang hampir seluruh kelompok umur di masyarakat. Salah satu klompok masyarakat yang memiliki prevalensi $\mathrm{ADB}$ yang tinggi adalah kelompok wanita hamil. Berbagai negara, termasuk Indonesia melaporkan angka prevalensi ADB pada wanita hamil tetap tinggi meskipun bervariasi lebar. Dimulai dari yang paling rendah ialah prevalensi ADB pada kehamilan di negara maju, yaitu rata-rata $18 \%$ sedangkan prevalensi rata-rata anemia pada wanita hamil di negara berkembang sekitar 63,5-80\%. Tingginya prevalensi ADB pada wanita hamil menimbulkan kehawatiran terhadap dampak buruk ADB dan nilai ekonomis yang timbul. Berbagai studi melaporkan bahwa ADB pada wanita hamil dapat menimbulkan dampak mulai saat dalam kandungan, setelah lahir, usia sekolah hingga pada masa dewasa. ${ }^{2}$

World Health Organization (WHO) melaporkan bahwa terdapat $52 \%$ ibu hamil di negara berkembang. Di Indonesia (Sensus dan Survei Depkes-Unicef) dilaporkan bahwa terdapat sekitar 4 juta ibu hamil, separuhnya mengalami anemia gizi dan satu juta lainnya mengalami kekurangan energi kronis. ${ }^{3}$ Ironisnya, diestimasi di bawah 50\% ibu tidak mempunyai cadangan zat besi atau yang cukup selama kehamilannya, sehingga risiko defiensi zat besi atau anemia meningkat bersama dengan kehamilan.

Salah satu yang menjadi global target trend 2025 ialah menurunkan angka anemia wanita usia reproduksi sebesar 50\%. ${ }^{4}$ Sangat menyedihkan oleh karena target tercapainya the millennium developmnet goals (MDGs) untuk negara-negara masih belum dicapai. Penduduk dunia yang menderita anemia kurang lebih masih 1,62 milyar terutama wanita usia muda. ${ }^{5}$

Anemia yang terbanyak menurut data Rikesdas 2013, pada wanita dewasa di Indonesia ialah tipe hipokrom mikrositik dan anemia jenis ini merupakan anemia yang paling sering disebabkan oleh defisiensi besi yang terbanyak diderita oleh ibu hamil. Wanita hamil membutuhkan $1000 \mathrm{mg}$ besi perhari untuk pertambahan volume darah maternal dan masa sel-sel darah merah fetal. Meskipun tingkat penyerapannya cukup tinggi namun anemia tetap terjadi umumnya anemia defisiensi besi. Transfer zat besi akan mengalami gangguan akibat defisiensi tersebut. Transfer tersebut diatur oleh plasenta. Selama kehamilan dan pada saat kelahiran terjadi penurunan hemoglobin $(\mathrm{Hb}) \mathrm{di}$ bawah $11 \mathrm{gr} / \mathrm{dl}$, yang hingga saat kini menjadi masalah kesehatan masyarakat di negara berpenghasilan rendah dan negara menengah. Diperkirakan sekitar 30-60\% wanita hamil menderita anemia. ${ }^{6}$

Hasil penelitian Tazkiah et al. ${ }^{7}$ menyebutkan bahwa terdapat hubungan bermakna antara BBLR dan kejadian anemia pada ibu hamil. Hasil penelitian tersebut menunjukkan bahwa, kejadian BBLR pada ibu hamil yang anemia terbanyak pada usia 26-30 tahun.

Masalah pengetahuan atau pendidikan dan keterbatasan ekonomi dapat mendorong ibu hamil tidak melakukan pemeriksaan rutin karena tidak mampu membayar. Selain itu, rendahnya tingkat pendidikan yang mengakibatkan kurangnya pengetahuan tentang kehamilan atau kelainankelainan dalam kehamilan kurang diperhatikan yang pada akhirnya dapat membawa risiko yang tidak diinginkan. Akibat dari rendahnya pengetahuan ibu hamil tidak jarang kehamilan banyak menimbulkan kematian baik pada ibu maupun pada bayi yang dilahirkan atau bahkan keduanya. ${ }^{8}$

Berdasarkan uraian di atas, penulis tertarik untuk melakukan penelitian tentang faktor-faktor penyebab anemia pada ibu 
hamil di wilayah kerja Puskesmas Mopuya.

\section{METODE PENELITIAN}

Jenis penelitian ini ialah analitik deskriptif dengan desain potong lintang yang dilakukan pada bulan NoemberDesember 2017. Pengambilan responden dilakukan di Puskesmas Mopuya.

\section{HASIL PENELITIAN}

Responden dalam penelitian ini ialah ibu hamil yang datang ke Puskesmas Mopuya berjumlah 66 orang ibu hamil. Tabel 1 memperlihatkan distribusi karakteristik responden. Untuk distribusi berdasarkan usia ibu, responden dengan kategori usia 21-35 tahun yang terbanyak $(77,3 \%)$ sedangkan yang terendah ialah usia $>35$ tahun $(7,6 \%)$. Mengenai pekerjaan suami responden lebih banyak memilki suami yang bekerja (100\%); tidak didapatkan suami yang tidak bekerja $(0 \%)$. Untuk pekerjaan responden lebih banyak sebagai ibu rumah tangga, yaitu 66,7\%, sedangkan responden yang bekerja, yaitu 33,3\%. Responden dengan suami yang berlatar belakang tamat SMA paling banyak yaitu $69,7 \%$, disusul oleh SMP 16,7\%, SD $12,1 \%$, dan diploma yaitu $1,5 \%$.

Tabel 2 menunjukkan jumlah responden yang memiliki jumlah terbanyak yaitu yang memiliki kadar hemoglobin $(\mathrm{Hb})<11$ $\mathrm{g} / \mathrm{dl}$ yaitu sebanyak 49 orang $(74,2 \%)$

Tabel 3 memperlihatkan distribusi kadar $\mathrm{Hb}$ dengan karakteristik responden berdasarkan kadar $\mathrm{Hb}$ ibu hamil <11 g/dl sebanyak 49 orang $(74,2 \%)$. Dalam penelitian ini lebih banyak ditemukan ibu hamil dengan kadar $\mathrm{Hb}$ yang tidak normal. Distribusi kadar $\mathrm{Hb}$ dengan karakteristik responden berdasarkan usia ditemukan lebih banyak responden dengan kadar $\mathrm{Hb}$ $<11 \mathrm{~g} /$ dl pada kategori usia 21-35 tahun $(77,6 \%)$ dan kadar $\mathrm{Hb}<11 \mathrm{~g} / \mathrm{dl}$ terendah pada responden berusia $>35$ tahun $(8,2 \%)$. Distribusi hemoglobin berdasarkan pekerjaan suami, responden dengan kadar $\mathrm{Hb}$ $<11 \mathrm{~g} / \mathrm{dl}$ terdapat pada suami dengan status pekerjaan bekerja (74,2\%). Distribusi kadar $\mathrm{Hb}$ berdasarkan pekerjaan responden dengan kadar $\mathrm{Hb}<11 \mathrm{~g} / \mathrm{dl}$ terbanyak pada responden dengan status pekerjaan bekerja $(38,8 \%)$. Distribusi kadar hemoglobin berdasarkan pendidikan suami responden dengan kadar $\mathrm{Hb}<11 \mathrm{~g} / \mathrm{dl}$ lebih banyak pada pendidikan suami SMA $(69,4 \%)$. Distribusi kadar $\mathrm{Hb}$ berdasarkan pendidikan responden $<11 \mathrm{~g} / \mathrm{dl}$ lebih banyak pada pendidikan responden yang tamat SMA sederajat $(46,9 \%)$.

Tabel 1. Karakteristik responden

\begin{tabular}{lcc}
\hline \multicolumn{1}{c}{ Karakteristik } & n & \% \\
\hline Ibu hamil & 66 & 100 \\
\hline Usia (Tahun) & & \\
$<20$ & 10 & 15,2 \\
$21-35$ & 51 & 77,3 \\
$>35$ & 5 & 7,6 \\
\hline Pekerjaan suami: & & \\
Tidak bekerja & 0 & 0 \\
Bekerja & 66 & 100 \\
\hline Pekerjaan istri: & & \\
Ibu rumah tangga & 44 & 66,7 \\
Bekerja & 22 & 33,3 \\
Pendidikan & & \\
suami: & 8 & 12,1 \\
Tamat SD & 11 & 16,7 \\
Tamat & 46 & 69,7 \\
SLTP/SMP & 1 & 1,5 \\
Tamat SMA & & \\
Tamat Diploma & & \\
\hline Pendidikan istri: & & \\
Tamat SD & 8 & 12,1 \\
Tamat & 22 & 33,3 \\
SLTP/SMP & 29 & 43,9 \\
Tamat SMA & 1 & 1,5 \\
Tamat Diploma & & \\
\hline Penghasilan & & \\
suami & \\
<UMP & 53 & 80,3 \\
$>$ UMP & 13 & 9,7 \\
\hline
\end{tabular}

Tabel 2. Distribusi responden berdasarkan kadar hemoglobin

\begin{tabular}{lcc}
\hline Kadar hemoglobin & N & \% \\
\hline $\mathrm{Hb}<11 \mathrm{~g} / \mathrm{dl}$ & 49 & 74,2 \\
$\mathrm{Hb}>11 \mathrm{~g} / \mathrm{dl}$ & 17 & 25,8 \\
Total & 66 & 100 \\
\hline
\end{tabular}

Tabel 4 memperlihatkan bahwa beras merupakan bahan makanan yang paling sering dikonsumsi responden $(98,48 \%)$, 
diikuti dengan minyak kelapa yang menempati urutan kedua sebagai bahan makanan tersering yang dikonsumsi responden $(92,42 \%)$. Daging sapi dan daging babi hanya sering dikonsumsi oleh sebagian kecil responden $(6,06 \%)$.

Tabel 3. Distribusi kadar hemoglobin berdasarkan karakteristik responden

\begin{tabular}{|c|c|c|c|c|}
\hline \multirow{3}{*}{ Karakeristik } & \multicolumn{4}{|c|}{ Kadar hemoglobin } \\
\hline & \multicolumn{2}{|c|}{$<11 \mathrm{~g} / \mathrm{dl}$} & \multicolumn{2}{|c|}{$>11 \mathrm{gr} / \mathrm{dl}$} \\
\hline & $\mathrm{n}$ & $\%$ & $\mathrm{~N}$ & $\%$ \\
\hline Ibu hamil & 49 & 74,2 & 17 & 25,8 \\
\hline \multicolumn{5}{|l|}{ Usia (Tahun) } \\
\hline$<20$ & 7 & 14,3 & 3 & 6,1 \\
\hline $21-35$ & 38 & 77,6 & 13 & 26,5 \\
\hline$>35$ & 4 & 8,2 & 2 & 4,1 \\
\hline \multicolumn{5}{|l|}{ Pekerjaan suami: } \\
\hline Tidak bekerja & 0 & 0 & 0 & 0 \\
\hline Bekerja & 49 & 74,2 & 0 & 0 \\
\hline \multicolumn{5}{|l|}{ Pekerjaan istri: } \\
\hline Ibu Rumah Tangga & 30 & 61,2 & 13 & 25,5 \\
\hline Bekerja & 19 & 38,8 & 4 & 8,2 \\
\hline \multicolumn{5}{|l|}{ Pendidikan suami } \\
\hline Tamat SD & 5 & 10,2 & 2 & 4,1 \\
\hline Tamat SLTP/SMP & 10 & 20,4 & 2 & 4,1 \\
\hline Tamat SMA & 34 & 69,4 & 13 & 26,5 \\
\hline Tamat Diploma & 0 & 0 & 0 & 0 \\
\hline \multicolumn{5}{|l|}{ Pendidikan istri : } \\
\hline Tamat SD & 10 & 20,4 & 1 & 2,0 \\
\hline Tamat SLTP/SMP & 10 & 20,4 & 4 & 8,2 \\
\hline Tamat SMA & 23 & 46,9 & 10 & 20,4 \\
\hline Tamat Diploma & 4 & 8,2 & 3 & 6,1 \\
\hline
\end{tabular}

Tabel 4. Distribusi frekuensi tertinggi bahan makanan yang sering dikonsumsi berdasarkan kelompok makanan FFQ

\begin{tabular}{|c|c|c|c|}
\hline \multirow[t]{2}{*}{$\begin{array}{c}\text { Kelompok } \\
\text { makanan }\end{array}$} & $\begin{array}{c}\text { Frekuensi } \\
\text { tertinggi kategori } \\
\text { sering }\end{array}$ & & \multirow[t]{2}{*}{ Bahan makanan } \\
\hline & $\%$ & & \\
\hline I & 66 & 98,48 & Beras \\
\hline II & 17 & 25,76 & Tahu \\
\hline \multirow[t]{2}{*}{ III } & 4 & 6,06 & Daging Sapi \\
\hline & 4 & 6,06 & Daging Babi \\
\hline IV & 49 & 74,24 & Ikan Air Laut \\
\hline V & 27 & 40,91 & Tomat Masak \\
\hline VI & 16 & 24 & Telur Ayam \\
\hline VII & 33 & 50,00 & Pisang \\
\hline VIII & 61 & 92,42 & Minyak Kelapa \\
\hline IX & 31 & 46,97 & Garam Dapur \\
\hline
\end{tabular}

Tabel 5 memperlihatkan bahwa sebagian besar responden penelitian, mengonsumsi pepaya dalam frekuensi yang jarang yaitu sebanyak 13 orang $(42,42 \%)$. Mie merupakan bahan makanan kedua yang dikonsumsi sebagian besar responden 
dalam frekuensi yang jarang $(69,70 \%)$.

Tabel 6 menampilkan bahwa sebanyak 66 responden, semuanya tidak pernah mengonsumsi kelapa tua, kepiting, manggis, nanas dan yogurt (100\%). Hampir seluruh responden penelitian tidak pernah makan telur bebek asin $(98,48 \%)$. Singkong merupakan bahan makanan paling sedikit yang tidak pernah dikonsumsi $(71,2 \%)$.

Tabel 5. Distribusi frekuensi tertinggi bahan makanan yang jarang dikonsumsi berdasarkan kelompok makanan FFQ

\begin{tabular}{cccl}
\hline $\begin{array}{c}\text { Kelompok } \\
\text { makanan }\end{array}$ & $\begin{array}{c}\text { Frekuensi tertinggi kategori } \\
\text { jarang }\end{array}$ & \multicolumn{1}{c}{$\begin{array}{c}\text { Bahan } \\
\text { makanan }\end{array}$} \\
\cline { 2 - 3 } & $\mathrm{N}$ & $\%$ & Mie \\
I & 46 & 69,70 & Kelapa muda \\
II & 43 & 65,15 & Ayam \\
III & 57 & 83,36 & Ikan air tawar \\
IV & 38 & 57,58 & Bayam \\
V & 32 & 48,48 & Telur ayam \\
VI & 36 & 54,55 & Pepaya \\
VII & 13 & 42,42 & Mentega \\
VIII & 5 & 7,58 & Gula pasir \\
IX & 37 & 20,44 & \\
\hline
\end{tabular}

Table 6. Distribusi frekuensi tertinggi bahan makanan yang tak pernah dikonsumsi berdasarkan kelompok makanan FFQ

\begin{tabular}{cccl}
\hline \multirow{2}{*}{$\begin{array}{c}\text { Kelompok } \\
\text { makanan }\end{array}$} & \multicolumn{2}{c}{$\begin{array}{c}\text { Frekuensi tertinggi } \\
\text { kategori tidak pernah }\end{array}$} & Bahan makanan \\
\cline { 2 - 3 } & $\mathrm{N}$ & $\%$ & \\
\hline I & 47 & 71,2 & Singkong \\
II & 66 & 100 & Kelapa tua \\
III & 66 & 100 & Kepiting \\
IV & 65 & 98,48 & Corned beef \\
V & 63 & 34,81 & Bengkoang \\
& 63 & 95,45 & Kembang kol/brokoli \\
VI & 65 & 98,48 & Telur bebek asin \\
VII & 66 & 100 & Manggis \\
& 66 & 100 & Nanas \\
VIII & 66 & 100 & Yogurt \\
IX & 65 & 98,48 & Kerupuk ikan \\
\hline
\end{tabular}

Tabel 7 memperlihatkan bahwa berdasarkan kandungan karbohidrat, dapat dilihat bahwa beras merupakan bahan makanan sumber karbohidrat yang paling sering dikonsumsi responden $(98,48 \%)$. Pepaya merupakan bahan makanan yang masuk dalam kategori frekuensi jarang, yaitu sebanyak 13 orang $(42,42 \%)$. Banyak responden tidak pernah mengon-sumsi singkong sebagai sumber karbohidrat $(71,2 \%)$. Berdasarkan zat gizi protein, diperoleh hasil bahwa ikan air laut merupakan bahan makanan sumber protein yang paling sering dikonsumsi responden, $(74,24 \%)$ sedangkan ayam merupakan bahan makanan sumber protein yang jarang dikonsumsi oleh responden (86,36\%). Corned beef merupakan bahan makanan yang tidak pernah dikonsumsi oleh seluruh responden (100\%). Berdasarkan bahan makanan sumber lemak, minyak kelapa merupakan bahan makanan yang paling sering dikonsumsi responden (92,42\%). Bahan makanan sumber lemak yang jarang 
dikonsumsi responden yaitu mentega, $(24,86 \%)$. Juga didapatkan sebanyak 60 responden $(90,91 \%)$ tidak pernah mengonsumsi yogurt sebagai bahan makanan yang kaya lemak.

Tabel 8 memaparkan bahwa berdasarkan hasil rata-rata konsumsi per-hari, responden paling banyak mengonsumsi kelompok makanan $\mathrm{V}$ yaitu kelompok sayur dan hasil olahannya, dengan rata-rata konsumsi sebesar 2410,60 gr/hari. Kelopok makanan IX, yaitu serba-serbi merupakan kelompok makanan yang paling sedikit dikonsumsi responden, dengan ratarata konsumsi hanya $66,62 \mathrm{gr} / \mathrm{hari}$.

Tabel 7. Distribusi frekuensi tertinggi konsumsi bahan makanan per kategori frekuensi berdasarkan kandungan zat gizi makro

\begin{tabular}{lcccc}
\hline \multirow{2}{*}{ Zat Gizi } & \multicolumn{3}{c}{ Frekuensi tertinggi } & Bahan \\
\cline { 2 - 5 } & n & $\%$ & $\begin{array}{c}\text { Kelompok } \\
\text { makananan }\end{array}$ \\
\hline Karbohidrat & & & & \\
-Sering & 65 & 98,48 & Beras & I \\
-Jarang & 13 & 42,42 & Papaya & VII \\
-Tidak pernah & 47 & 71,2 & Singkong & I \\
\hline Protein & 49 & 74,24 & Ikan air laut & IV \\
-Sering & 52 & 86,36 & Ayam & III \\
-Jarang & 66 & 100 & Corned beef & III \\
-Tidak pernah & & & & \\
Lemak & 61 & 92,42 & Minyak kelapa & VIII \\
-Sering & 5 & 7,58 & Mentega & VIII \\
-Jarang & 60 & 90.91 & Yogurt & VIII \\
-Tidak pernah & &
\end{tabular}

Tabel 8. Rata-rata konsumsi makanan berdasarkan kelompok makanan FFQ

\begin{tabular}{clc}
\hline \multicolumn{1}{c}{ Kelompok makanan } & $\begin{array}{c}\text { Rata-rata konsumsi } \\
\text { per hari (gr/hari) }\end{array}$ \\
\hline I & Serealia, umbi-umbian dan hasil & 2177,20 \\
& olahannya & \\
II & Kacang-kacangan, biji-bijian dan hasil & 1228,30 \\
& olahannya & \\
III & Daging dan hasil olahannya & 1066,86 \\
IV & Ikan, kerang, udang, dan hasil olahannya & 919,36 \\
V & Sayur dan hasil olahannya & 2410,60 \\
VI Telur & 353,80 \\
VII Buah-buahan & 2499,61 \\
VIII Susu dan lemak & 424,10 \\
IX $\quad$ Serba-serbi & 66,62 \\
\hline
\end{tabular}

Tabel 9 menampilkan bahwa berdasarkan olah statistik rata-rata konsumsi makanan per-hari, beras merupakan bahan makanan yang paling banyak dikonsumsi responden perharinya yaitu sebanyak $678,41 \mathrm{~g} / \mathrm{hari}$, diikuti dengan daging sapi sebesar 250gr/hari, dan tahu dengan jumlah rata-rata sebesar 220gr/hari sedangkan corned beef, kepiting dan yougurt merupakan bahan makanan yang tidak pernah di konsumsi responden dengan ratarata 0,00gr/hari. Bahan makanan yang paling sedikit dikonsumsi responden ialah kerupuk ikan, yaitu hanya sebesar $0,05 \mathrm{gr} /$ hari dan diikuti oleh bengkoang dengan rata-rata sebesar $0,02 \mathrm{gr} / \mathrm{hari}$. 
Tabel 10 memaparkan bahwa berdasarkan zat gizi karbohidrat, beras merupakan bahan makanan sumber karbohidrat yang paling banyak di konsumsi responden tiap harinya, yaitu sebesar 678,41gr/hari. Bengkoang merupakan bahan makanan sumber karbohidrat yang paling sedikit dikonsumsi per-harinya, yaitu hanya sebesar 0,12 gr/hari. Berdasarkan zat gizi protein, dapat dilihat bahwa daging sapi merupakan bahan makanan yang paling banyak dikonsumsi responden, yaitu dengan rata-rata sebesar $250 \mathrm{~g} / \mathrm{hari}$, sedang- kan kepiting merupakan bahan makanan sumber protein yang mempunyai rata-rat konsumsi 0 gr/hari, yang berarti bahwa kepiting sama sekali tidak pernah dikonsumsi responden. Zat gizi yang terakhir ialah lemak, dapat dilihat bahwa responden banyak mengonsumsi minak kelapa sebagai sumber lemak, yaitu sebanyak 200 gr/hari. Responden paling sedikit mengon-sumsi yogurt, yaitu rata-rata sebesar 0 gr/hari, yang berarti bahwa yogurt sama sekali tidak pernah dikonsumsi responden.

Tabel 9. Rata-rata konsumsi bahan makanan tertinggi dan terendah berdasarkan kelompok makanan FFQ

\begin{tabular}{cclcl}
\hline KM & $\begin{array}{c}\text { Rata-rata } \\
\text { tertinggi } \\
\text { (gr/hari) }\end{array}$ & Bahan makanan & $\begin{array}{c}\text { Rata-rata } \\
\text { terendah } \\
\text { (gr/hari) }\end{array}$ & Bahan makanan \\
\hline I & 678,41 & Beras & 120 & Singkong \\
II & 220 & Tahu & 100 & Kelapa tua \\
III & 250 & Daging sapi & 0 & Corned beef \\
IV & 150 & Ikan air laut & 0 & Kepiting \\
V & 200 & Tomat masak & 0,02 & Bengkoang \\
VI & 55 & Telur ayam & 55 & Telur bebek asin \\
VII & 60 & Pisang & 55 & Manggis \\
VII & 200 & Minayak kelapa & 0 & Yougurt \\
IX & 7,5 & Garam dapur & 0,5 & Kerupuk ikan \\
\hline
\end{tabular}

Tabel 10. Rata-rata konsumsi bahan makanan tertinggi dan terendah berdasarkan zat gizi makro

\begin{tabular}{lclcc}
\hline \multicolumn{1}{c}{ Zat gizi } & $\begin{array}{c}\text { Rata-rata } \\
\text { tertinggi } \\
(\mathbf{g r} / \mathbf{h a r i})\end{array}$ & \multicolumn{1}{c}{$\begin{array}{c}\text { Bahan } \\
\text { makanan }\end{array}$} & $\begin{array}{c}\text { Rata-rata } \\
\text { terendah } \\
(\mathbf{g r} / \mathbf{d l})\end{array}$ & $\begin{array}{c}\text { Bahan } \\
\text { makanan }\end{array}$ \\
\hline Karbohidrat & 678,41 & Beras & Bengkoang & 0,02 \\
Protein & 250 & Daging sapi & $\begin{array}{l}\text { Kepiting } \\
\text { Yogurt }\end{array}$ & 0 \\
Lemak & 200 & Minyak kelapa & & 0 \\
\hline
\end{tabular}

Tabel 11 memaparkan bahwa kadar $\mathrm{Hb}$ $<11 \mathrm{~g} / \mathrm{dl}$ didapatkan terbanyak pada responden yang berusia $21-35$ tahun $(59,1 \%)$ dan terdapat 12 orang $(18,2 \%)$ dengan kadar $\mathrm{Hb}$ $>11 \mathrm{~g} / \mathrm{dl}$. Responden yang berusia >35 tahun memiliki kadar $\mathrm{Hb}>11 \mathrm{~g} / \mathrm{dl}$ yaitu 6 orang $(7,6 \%)$. Dengan hasil uji Chi-Square Test diperoleh nilai $P=0,00$ yang lebih kecil dari $\alpha=0,05$. Hal ini menunjukkan adanya hubungan bermakna antara kadar hemoglobin dan usia ibu hamil.
Tabel 12 memperlihatkan bahwa kadar $\mathrm{Hb}<11 \mathrm{~g} / \mathrm{dl}$ didapatkan pada trimester I sebanyak 13 orang $(19,7 \%)$; pada trimester II sebanyak 29 orang $(43,9 \%)$; pada trimester III sebanyak 7 orang $(10,6 \%) ; 17$ orang $(25,8 \%)$ responden memiliki $\mathrm{Hb}>11$ g/dl pada trimester III. Hasil uji Chi-square mendapatkan nilai $P=0,00$ yang lebih kecil dari $\alpha=0,05$. Hal ini menunjukkan bahwa terdapat hubungan bermakna antara kadar hemoglobin dan usia kehamilan responden. 
Tabel 11. Hubungan antara kadar hemoglobin $(\mathrm{Hb})$ dengan usia responden

\begin{tabular}{ccccc}
\hline & \multicolumn{3}{c}{ Usia ibu hamil } & \\
\cline { 2 - 4 } Kadar & $<20$ tahun & $21-35$ tahun & $>35$ tahun \\
hemoglobin & $\mathrm{n}(\%)$ & $\mathrm{n}(\%)$ & $\mathrm{P}(\%)$ & $\boldsymbol{P}^{(\boldsymbol{\alpha}=\mathbf{0 , 0 5})}$ \\
\hline$<11 \mathrm{~g} / \mathrm{dl}$ & $10(15,2)$ & $39(59,1)$ & $0(0)$ & \\
$>11 \mathrm{~g} / \mathrm{dl}$ & $0(0)$ & $12(18,2)$ & $6(7,6)$ & 0,000 \\
Total & 10 & 51 & 6 & \\
\hline
\end{tabular}

Tabel 12. Hubungan antara kadar hemoglobin $(\mathrm{Hb})$ dengan usia kehamilan responden

\begin{tabular}{cccccc}
\hline Kadar & \multicolumn{3}{c}{ Usia kehamilan } & \multirow{2}{*}{ Total } & \multirow{2}{*}{$\mathbf{P}^{(\boldsymbol{a}=\mathbf{0}, \mathbf{0 5})}$} \\
\cline { 2 - 4 } & $\begin{array}{c}\text { Trimester 1 } \\
(0-3) \text { bulan }(\%)\end{array}$ & $\begin{array}{c}\text { Trimester } 2 \\
(4-6) \text { bulan }(\%)\end{array}$ & $\begin{array}{c}\text { Trimester 3 } \\
(>7) \text { bulan }(\%)\end{array}$ & & \\
\hline $\mathrm{Hb}<11 \mathrm{~g} / \mathrm{dl}$ & $13(19,7)$ & $29(43,9)$ & $7(10,6)$ & 49 & 0,000 \\
$\mathrm{Hb}>11 \mathrm{~g} / \mathrm{dl}$ & 0 & 0 & $17(25,8)$ & 17 & \\
\hline
\end{tabular}

Tabel 13 mendapatkan bahwa paritas responden yang belum pernah melahirkan, memiliki $\mathrm{Hb}<11 \mathrm{~g} / \mathrm{dl}$ yaitu 22 orang $(33,3 \%)$. Paritas responden $<2$ kelahiran memiliki $\mathrm{Hb}<11 \mathrm{~g} / \mathrm{dl}$ yaitu 23 orang $(34,8 \%)$ sedangkan responden yang $>2$ kelahiran memiliki kadar $\mathrm{Hb}>11 \mathrm{~g} / \mathrm{dl}$ yaitu 4 orang $(6,1 \%)$, dan kadar $\mathrm{Hb}<11 \mathrm{~g} / \mathrm{dl}$ yaitu 17 orang $(25,8 \%)$. Uji Chi-square memperoleh nilai $P=0,00$ yang lebih kecil dari $\alpha=0,05$. Hal ini menunjukkan bahwa terdapat hubungan bermakna antara kadar hemoglobin dan paritas responden.

Tabel 14 memperlihatkan bahwa jarak kehamilan responden yang belum melahir- kan memiliki $\mathrm{Hb}<11$ g/dl yaitu 23 orang $(34,8 \%)$. Pada responden dengan jarak paritas <2 tahun memiliki $\mathrm{Hb}<11 \mathrm{~g} / \mathrm{dl}$ yaitu 1 orang $(1,5 \%)$. Pada responden dengan jarak paritas >2 tahun yang memiliki $\mathrm{Hb}<11 \mathrm{~g} / \mathrm{dl}$ yaitu 25 orang (37,9\%), sedangkan pada responden yang jarak paritas $>2$ tahun memiliki $\mathrm{Hb}>11$ g/dl yaitu 17 orang $(25,8 \%)$. Hasil uji Chisquare memperoleh nilai $P=0,01$ yang lebih kecil dari $\alpha=0,05$. Hal ini menunjukkan bahwa terdapat hubungan bermakna antara kadar hemoglobin dan jarak kehamilan responden.

Tabel 13. Hubungan antara kadar hemoglobin $(\mathrm{Hb})$ dengan paritas responden

\begin{tabular}{|c|c|c|c|c|c|}
\hline \multirow{2}{*}{$\begin{array}{l}\text { Kadar } \\
\text { hemoglobin }\end{array}$} & \multicolumn{3}{|c|}{ Paritas } & \multirow[b]{2}{*}{ Total } & \multirow[b]{2}{*}{$\mathbf{P}^{(\alpha=0,05)}$} \\
\hline & $\begin{array}{l}\text { Belum pernah } \\
\text { melahirkan }(\%)\end{array}$ & $\begin{array}{c}<2 \text { anak } \\
(\%)\end{array}$ & $\begin{array}{c}>2 \text { anak } \\
(\%)\end{array}$ & & \\
\hline $\mathrm{Hb}<11 \mathrm{~g} / \mathrm{dl}$ & $22(33,3)$ & $23(34,8)$ & $4(6,1)$ & 4 & \\
\hline $\mathrm{Hb}>11 \mathrm{~g} / \mathrm{dl}$ & $0(0)$ & $0(0)$ & $17(25,8)$ & 17 & 0,000 \\
\hline Total & 22 & 23 & 21 & 21 & \\
\hline
\end{tabular}

Tabel 14. Hubungan antara kadar hemoglobin $(\mathrm{Hb})$ dengan jarak kehamilan responden

\begin{tabular}{|c|c|c|c|c|c|}
\hline \multirow[b]{2}{*}{ Hemoglobin } & \multicolumn{3}{|c|}{ Jarak kehamilan } & \multirow[b]{2}{*}{ Total } & \multirow[b]{2}{*}{$P\left({ }^{\alpha=0.05)}\right.$} \\
\hline & $\begin{array}{c}\text { Belum } \\
\text { melahirkan } \\
(\%)\end{array}$ & $\begin{array}{c}<2 \text { Tahun } \\
(\%)\end{array}$ & $\begin{array}{l}>2 \text { Tahun } \\
(\%)\end{array}$ & & \\
\hline $\mathrm{Hb}<11 \mathrm{~g} / \mathrm{dl}$ & $23(34,8)$ & $1(1,5)$ & $25(37,9)$ & 49 & \\
\hline $\mathrm{Hb}>11 \mathrm{~g} / \mathrm{d}$ & $0(0)$ & $0(0)$ & $17(25,8)$ & 17 & 0,01 \\
\hline Total & 23 & 1 & 42 & 66 & \\
\hline
\end{tabular}


Tabel 15 menampilkan bahwa pada responden dengan LILA $<23,5 \mathrm{~cm}$ memiliki kadar $\mathrm{Hb}<11 \mathrm{~g} / \mathrm{dl}$ yaitu 21 orang $(31,8 \%)$. Pada responden dengan LILA $>23,5 \mathrm{~cm}$ memiliki kadar $\mathrm{Hb}<11 \mathrm{~g} / \mathrm{dl}$ yaitu 28 orang $(42,4 \%)$ sedangkan responden yang ukuran Lila $>23,5 \mathrm{~cm}$ memiliki kadar $\mathrm{Hb}>11 \mathrm{~g} / \mathrm{dl}$ yaitu 17 orang $(25,8 \%)$. Hasil uji Chi-square memperoleh nilai $P=0,01$ yang lebih kecil dari $\alpha=0,05$. Hal ini menunjukkan bahwa terdapat hubungan bermakna antara kadar hemoglobin dan ukuran LILA responden.

Pada Tabel 16 terlihat bahwa sebanyak 6 orang $(9,1 \%)$ dengan status pekerjaan tidak bekerja dan bekerja memiliki kadar $\mathrm{Hb}<11 \mathrm{~g} / \mathrm{dl}$. Sebanyak 17 orang $(25,8 \%)$ dengan status pekerjaan bekerja memiliki $\mathrm{Hb}>11 \mathrm{~g} / \mathrm{dl}$. Sebanyak 37 orang $(56,1 \%)$ memiliki kadar $\mathrm{Hb}<11 \mathrm{~g} / \mathrm{dl}$ dengan status pekerjaan IRT. Hasil uji Chi-square memperoleh nilai $P=0,00$ yang lebih kecil dari $\alpha=0,05$. Hal ini menunjukkan bahwa terdapat hubungan bermakna antara kadar hemoglobin dan status pekerjaan responden.

Tabel 17 menunjukan bahwa pada responden dengan pendidikan tamat SD, yang terbanyak ialah memiliki kadar $\mathrm{Hb}$ $<11 \mathrm{~g} / \mathrm{dl}(13,6 \%)$. Kadar $\mathrm{Hb}<11 \mathrm{~g} / \mathrm{dl}$ pada responden tamat SMP yaitu 17 orang (25,8\%); dan pada responden tamat SMA yaitu 23 orang $(34,8 \%)$. Pada responden tamat SMA yaitu 10 orang $(15,2 \%)$ memiliki kadar $\mathrm{Hb}>11 \mathrm{~g} / \mathrm{dL}$. Dengan hasil uji Chi-square Test diperoleh hasil nilai $P=$ 0,00 yang lebih kecil dari $\alpha=0,05$. Hal ini menunjukkan bahwa terdapat hubungan antara kadar hemoglobin dan status pendidikan responden.

Tabel 15. Hubungan antara kadar hemoglobin $(\mathrm{Hb})$ dengan ukuran LILA responden

\begin{tabular}{|c|c|c|c|c|}
\hline \multirow[t]{2}{*}{ Hemoglobin } & \multicolumn{2}{|c|}{ Ukuran LILA } & \multirow[b]{2}{*}{ Total } & \multirow[b]{2}{*}{$P^{(\alpha=0,05)}$} \\
\hline & $<23,5 \mathrm{~cm}(\%)$ & $>23,5 \mathrm{~cm}(\%)$ & & \\
\hline $\mathrm{Hb}<11 \mathrm{~g} / \mathrm{dl}$ & $21(31,8)$ & $28(42,4)$ & 49 & \\
\hline $\mathrm{Hb}>11 \mathrm{~g} / \mathrm{dl}$ & $0(0)$ & $17(25,8)$ & 17 & 0,01 \\
\hline Total & 21 & 45 & 66 & \\
\hline
\end{tabular}

Tabel 16. Hubungan antara kadar hemoglobin $(\mathrm{Hb})$ dengan status pekerjaaan responden

\begin{tabular}{lccccc}
\hline Kadar & \multicolumn{3}{c}{ Status Pekerjaan } & \multirow{2}{*}{ Total } & \multirow{P}{*}{$\left(\begin{array}{c}\mathbf{a}=\mathbf{0}, \mathbf{0 5}) \\
\text { hemoglobin }\end{array}\right.$} \\
\cline { 2 - 4 } & $\begin{array}{c}\text { Tidak bekerja } \\
(\%)\end{array}$ & $\begin{array}{c}\text { IRT } \\
(\%)\end{array}$ & $\begin{array}{c}\text { Bekerja } \\
(\%)\end{array}$ & & \\
\hline $\mathrm{Hb}<11 \mathrm{~g} / \mathrm{dl}$ & $6(9,1)$ & $37(56,1)$ & $6(9,1)$ & 49 & \\
$\mathrm{Hb}>11 \mathrm{~g} / \mathrm{dl}$ & $0(0)$ & $0(0)$ & $17(25,8)$ & 17 & 0,000 \\
Total & 6 & 37 & 23 & 66 & \\
\hline
\end{tabular}

Tabel 17. Hubungan antara kadar hemoglobin $(\mathrm{Hb})$ dengan status pendidikan responden

\begin{tabular}{lcccccc}
\hline \multirow{2}{*}{$\begin{array}{c}\text { Kadar } \\
\text { hemoglobin }\end{array}$} & $\begin{array}{c}\text { Tamat SD } \\
(\boldsymbol{\%})\end{array}$ & $\begin{array}{c}\text { Tamat SMP } \\
(\boldsymbol{\%})\end{array}$ & $\begin{array}{c}\text { Tamat SMA } \\
(\boldsymbol{\%})\end{array}$ & $\begin{array}{c}\text { Tamat } \\
\text { diploma }(\boldsymbol{\%})\end{array}$ & Total & $\begin{array}{c}\boldsymbol{P} \\
(\boldsymbol{\alpha}=\mathbf{0}, \mathbf{0 5})\end{array}$ \\
\hline $\mathrm{Hb}<11 \mathrm{~g} / \mathrm{dl}$ & $9(13,6)$ & $17(25,8)$ & $23(34,8)$ & $0(0)$ & 49 & \\
$\mathrm{Hb}>11 \mathrm{~g} / \mathrm{dl}$ & $0(0)$ & $0(0)$ & $10(15,2)$ & $7(10,6)$ & 17 & 0,000 \\
Total & 9 & 17 & 33 & 7 & 66 & \\
\hline
\end{tabular}

Tabel 18 menunjukkan bahwa kadar $\mathrm{Hb}<11 \mathrm{~g} / \mathrm{dl}$ dengan pendapatan kurang dari UMP terdapat sebanyak 49 orang $(74,2 \%)$ dan pada pendapatan lebih dari
UMP sebanyak 10 orang $(15,2 \%)$. Berdasarkan kadar $\mathrm{Hb}>11 \mathrm{~g} / \mathrm{dl}$ terdapat penghasilan kurang dari UMP sebanyak 7 Orang (10,6\%). Dengan hasil uji Chi- 
square diperoleh nilai $P=0,00$ yang lebih kecil dari $\alpha=0,05$. Hal ini menunjukkan bahwa terdapat hubungan antara kadar hemoglobin dan pendapatan keluarga responden.

Tabel 19 memaparkan dari golongan makanan kacang-kacangan didapatkan nilai tertinggi responden yang sering mengonsumsi bahan makanan kacang-kacangan dengan kadar $\mathrm{Hb}<11 \mathrm{~g} / \mathrm{dl}$ yaitu 46 orang $(69,7 \%)$, sedangkan jarang dan tidak pernah tidak didapatkan. Responden yang sering mengonsumsi bahan makanan kacang-kacangan dengan kadar $\mathrm{Hb}>11$ g/dl sebanayak 10 orang $(21,7 \%)$, dan jarang 17 orang $(25,8 \%)$. Dari golongan makanan daging didapatkan nilai tertinggi responden yang sering mengonsumsi bahan makanan daging dengan kadar $\mathrm{Hb}<11$ gr/dl yaitu 42 orang $(63,6 \%)$, dan jarang 7 orang (10,6\%). Responden dengan kategori sering pada kadar $\mathrm{Hb}>11 \mathrm{~g} / \mathrm{dl}$ yaitu tidak ada $(0 \%)$, jarang 10 orang $(15,2 \%)$, dan tidak pernah yaitu 7 orang $(10,6 \%)$. Dari golongan makanan ikan nilai tertinggi responden yang sering mengonsumsi bahan makanan ikan dengan kadar $\mathrm{Hb}<11 \mathrm{~g} / \mathrm{dl}$ yaitu 49 orang $(74,2 \%)$ dan jarang tidak ada (0\%). Responden dengan kategori sering pada $\mathrm{Hb}>11 \mathrm{~g} / \mathrm{dl}$ yaitu 16 orang $(24,2 \%)$ jarang 1 orang $(1,5 \%)$, dan tidak pernah tidak ada (0\%). Dari golongan makanan telur didapatkan nilai tertinggi responden yang sering mengonsumsi bahan makanan daging dengan kadar $\mathrm{Hb}<11$ gr/dl yaitu 35 orang $(53,0 \%)$ dan jarang 14 orang $(21,2 \%)$. Responden dengan kategori sering pada $\mathrm{Hb}>11 \mathrm{~g} / \mathrm{dl}$ yaitu tidak ada (0\%), jarang 3 orang $(4,5 \%)$, dan tidak pernah 14 orang $(21,2 \%)$.

Tabel 18. Hubungan antara kadar hemoglobin $(\mathrm{Hb})$ dengan pendapatn keluarga berdasarkan UMP

\begin{tabular}{|c|c|c|c|c|}
\hline \multirow{2}{*}{$\begin{array}{c}\text { Kadar } \\
\text { hemoglobin }\end{array}$} & \multicolumn{2}{|c|}{ Penghasilan } & \multirow[b]{2}{*}{ Total } & \multirow{2}{*}{$P^{(\alpha=0,05)}$} \\
\hline & $<\operatorname{UMP}(\%)$ & $\begin{array}{c}>\text { UMP } \\
(\%)\end{array}$ & & \\
\hline $\mathrm{Hb}<11 \mathrm{gr} / \mathrm{dl}$ & $49(74,2)$ & $0(0)$ & 49 & \\
\hline $\mathrm{Hb}>11 \mathrm{gr} / \mathrm{dl}$ & $7(10,6)$ & $10(15,2)$ & 17 & 0,000 \\
\hline Total & 56 & 10 & 66 & \\
\hline
\end{tabular}

Tabel 19. Hubungan antara kadar hemoglobin $(\mathrm{Hb})$ dengan pola makan responden

\begin{tabular}{|c|c|c|c|c|c|}
\hline \multirow{3}{*}{$\mathbf{K M}$} & \multicolumn{4}{|c|}{$\begin{array}{l}\text { Frekuensi konsumsi protein } \\
\text { sering, jarang, tidak pernah per hari }\end{array}$} & \multirow[t]{3}{*}{$P^{(\boldsymbol{a}=0,05)}$} \\
\hline & \multicolumn{2}{|c|}{$\mathrm{Hb}<11 \mathrm{~g} / \mathrm{dl}$} & \multicolumn{2}{|c|}{$\mathrm{Hb}>11 \mathrm{~g} / \mathrm{dl}$} & \\
\hline & $\mathrm{N}$ & $\%$ & & $\%$ & \\
\hline \multicolumn{6}{|l|}{ II Kacang-kacangan } \\
\hline Sering & 46 & 69,7 & 10 & 21,7 & 0,000 \\
\hline Jarang & 0 & 0 & 17 & 25,8 & \\
\hline Tidak pernah & 0 & 0 & 0 & 0 & \\
\hline \multicolumn{6}{|l|}{ III Daging } \\
\hline Sering & 42 & 63,6 & 0 & 0 & 0,000 \\
\hline Jarang & 7 & 10,6 & 10 & 15,2 & \\
\hline Tidak pernah & 0 & 0 & 7 & 10,6 & \\
\hline \multicolumn{6}{|l|}{ IV Ikan } \\
\hline Sering & 49 & 74,2 & 16 & 24,2 & 0,87 \\
\hline Jarang & 0 & 0 & 1 & 1,5 & \\
\hline Tidak pernah & 0 & 0 & 0 & 0 & \\
\hline \multicolumn{6}{|l|}{ VI Telur } \\
\hline Sering & 35 & 53,0 & 0 & 0 & 0,000 \\
\hline Jarang & 14 & 21,2 & 3 & 4,5 & \\
\hline Tidak pernah & 0 & 0 & 14 & 21,2 & \\
\hline
\end{tabular}


Hasil uji Chi-square memperoleh nilai $P=0,000$ untuk bahan makanan kacanngkacangan, daging, dan telur yang lebih kecil dari nilai $\alpha=0,05$. Hal ini menunjukkan bahwa terdapat hubungan bermakna antara kadar hemoglobin dengan bahan makanan kacang-kacangan, daging, dan telur. Berbeda halnya dengan bahan makanan dari ikan yang memiliki nilai $P=0,87$ yang lebih besar dari nilai $\alpha=0,05$. Hal ini menunjukkan bahwa tidak terdapat hubungan antara kadar hemoglobin dengan bahan makanan dari ikan.

\section{BAHASAN}

\section{Karakteristik responden}

Hasil penelitian mendapatkan ibu hamil dengan anemia paling sering terdapat pada kelompok usia reproduktif sehat (2035 tahun) yaitu sebesar 74,4\% sedangkan kelompok usia dini (10-19 tahun) dan usia risiko tinggi (>35 tahun) memiliki persentase yang sama yaitu $12,8 \%$. Pada penelitian yang dilakukan Fahriansyah, jumlah ibu hamil anemia paling banyak berada pada kelompok usia 25-35 tahun yaitu sebesar $64,4 \%$, diikuti kelompok usia $<25$ tahun yang memiliki persentase jumlah ibu hamil dengan anemia sebesar 24,4\% sedangkan persentase jumlah ibu hamil anemia pada kelompok usia $>35$ tahun hanya11,1\%. Wintrobe (1997) menyatakan bahwa usia ibu dapat memengaruhi timbulnya anemia, yaitu semakin rendah usia ibu hamil maka semakin rendah kadar hemoglobin; hal ini membuktikan bahwa usia juga dapat menjadi faktor risiko. ${ }^{9}$

\section{Hasil pemeriksaan kadar $\mathrm{Hb}$}

Kadar hemoglobin merupakan parameter yang digunakan secara luas untuk menetapkan prevalensi anemia. Pada penelitian ini digunakan alat hemoglobin meter dengan mengambil darah kapiler jari ibu hamil karena harganya terjangkau dan lebih mudah dilaksanakan di tempat penelitian. Hasil pemeriksaan kadar $\mathrm{Hb}$ mendapatkan 49 orang $(74,2 \%)$ dengan kadar $\mathrm{Hb}<11$ g/dl dan 17 orang $(25,8 \%)$ dengan kadar kadar $\mathrm{Hb}>11 \mathrm{~g} / \mathrm{dl}$. Dampak anemia dapat berakibat fatal jika tidak segera diatasi yaitu dapat menyebabkan keguguran, partus prematus, inersia uteri, partus lama, atonia uteri, pendarahan, serta syok. ${ }^{10}$

\section{Distribusi kadar (Hb) berdasarkan karakteristik responden}

Pada penelitian ini didapatkan kadar hemoglobin ibu hamil <11 g/dl sebanyak 49 orang $(74,2 \%)$. Terdapat lebih banyak responden dengan kadar $\mathrm{Hb}<11 \mathrm{~g} / \mathrm{dl}$ pada kategori usia 21-35 tahun $(77,6 \%)$, suami yang bekerja $(74,2 \%)$, responden ibu rumah tangga $(61,2 \%)$, pendidikan suami responden tamat SMA $(69,4 \%)$, dan pendidikan responden tamat SMA $(46,9 \%)$.

\section{Hubungan antara kadar hemoglobin dan usia ibu hamil}

Ibu hamil yang termasuk dalam kelompok usia reproduksi sehat adalah ibu yang hamil pada usia antara 20-35 tahun. Ibu hamil dalam kelompok usia ini telah mempunyai organ reproduksi yang dapat berfungsi dengan baik. ${ }^{3}$ Hasil penelitian ini mendapatkan responden yang berusia $<20$ tahun memiliki kadar $\mathrm{Hb}<11 \mathrm{~g} / \mathrm{dl}$ yaitu 10 orang $(15,2 \%)$. Responden yang berusia 21-35 tahun memiliki kadar $\mathrm{Hb}<11 \mathrm{~g} / \mathrm{dl}$ yaitu 39 orang $(59,1 \%)$ dan terdapat 12 orang $(18,2 \%)$ dengan kadar $\mathrm{Hb}>11 \mathrm{~g} / \mathrm{dl}$ sedangkan responden yang berusia $>35$ tahun memiliki kadar $\mathrm{Hb}>11 \mathrm{~g} / \mathrm{dl}$ sebanyak 5 orang $(7,6 \%)$.

\section{Hubungan antara kadar $\mathrm{Hb}$ dan paritas}

Dari hasil penelitian ternyata semua bayi BBLR dilahirkan oleh ibu dengan paritas tidak berisiko $(<4)$, yang menunjukkan tidak hanya ibu yang memiliki paritas $>4$ yang berisiko melahirkan BBLR namun ibu dengan paritas <4, khususnya ibu dengan paritas 0 atau nulipara juga berisiko melahirkan BBLR. Hal ini mungkin dikarenakan pada ibu yang nulipara atau baru mengalami kehamilan yang pertama kali tidak mempunyai pengalaman kehamilan sehingga kelainan pada komplikasi yang dialami cukup besar seperti distosia persalinan dan kurang informasi tentang kehamilan yang akan memengaruhi berat lahir bayi. Dengan demikian ibu dengan 
paritas tidak berisiko juga berpeluang melahirkan bayi BBLR. Kehamilan yang berulang-ulang juga akan menyebabkan kerusakan pada dinding pembuluh darah uterus, yang dapat memengaruhi nutrisi ke janin pada kehamilan selanjutnya sehingga berpeluang melahirkan bayi dengan BBLR. $^{3}$

Pada penelitian ini didapatkan bahwa paritas responden yang tidak ada atau belum pernah melahirkan dan memiliki $\mathrm{Hb}$ $<11 \mathrm{~g} / \mathrm{dl}$ sebanyak 22 orang $(33,3 \%)$. Paritas responden $<2$ kelahiran memiliki $\mathrm{Hb}<11$ g/dl yaitu 23 orang $(34,8 \%)$ sedangkan responden yang $>2$ kelahiran memiliki kadar $\mathrm{Hb}>11 \mathrm{~g} / \mathrm{dl}$ yaitu 4 orang (6,1\%), dan kadar $\mathrm{Hb}<11 \mathrm{~g} / \mathrm{dl}$ yang dimiki oleh responden dengan $>2$ kelahiran yaitu 17 orang $(25,8 \%)$.

\section{Hubungan antara kadar Hb dan jarak kehamilan}

Salah satu peneyab yang dapat mempercepat terjadinya anemia pada ibu hamil yaitu jarak kehamilan pendek. Hal ini dikarenakan karena kondisi ibu masih belum pulih dan pemenuhan kebutuhan zat gizi belum optimal, sudah harus memenuhi kebutuhan nutrisi janin yang dikandung. Pada penelitian yang dilakukan Guatam juga didapatkan adanya hubungan bermakna antara jarak kehamilan dengan anemia pada ibu hamil. ${ }^{11}$

Dari hasil penelitian ini didapatkan bahwa jarak kehamilan responden yang tidak ada (belum pernah melahirkan) dengan kadar $\mathrm{Hb}<11 \mathrm{~g} / \mathrm{dl}$ yaitu 23 orang $(34,8 \%)$. Pada responden dengan jarak kehamilan $<2$ tahun memiliki $\mathrm{Hb}<11 \mathrm{~g} / \mathrm{dl}$ yaitu 1 orang $(1,5 \%)$. Pada responden dengan jarak kehamilan $>2$ tahun memiliki $\mathrm{Hb}<11 \mathrm{~g} / \mathrm{dl}$ yaitu 25 orang $(37,9 \%)$, sedangkan pada responden dengan jarak kehamilan $>2$ tahun memiliki $\mathrm{Hb}>11 \mathrm{~g} / \mathrm{dl}$ yaitu 17 orang $(25,8 \%)$.

\section{Hubungan antara kadar $\mathrm{Hb}$ dan ukuran LILA}

Ibu hamil dengan LILA $<23,5 \mathrm{~cm}$ cenderung mengalami KEK, yang berarti ibu sudah mengalami keadaan kurang gizi dalam jangka waktu yang telah lama. Bila hal ini terjadi maka kebutuhan nutrisi untuk proses tumbuh kembang janin menjadi terhambat, sehingga bayi yang dilahirkan berpeluang mengalami BBLR. Hal ini sesuai dengan penelitian yang dilakukan oleh Trihardiani ${ }^{12}$ yaitu bahwa ibu dengan KEK (LILA $<23,5 \mathrm{~cm}$ ) mempunyai risiko 7,3 kali lebih untuk melahirkan bayi BBLR dibandingkan ibu dengan tidak KEK (LILA $>23,5 \mathrm{~cm}$ ).

\section{Hubungan antara kadar Hb dan status perekjaan responden}

Mengenai hubungan antara kadar hemoglobin $(\mathrm{Hb})$ dengan status pekerjaan responden, didapatkan nilai $P=0,000$ $(<0,05)$. Hasil penelitian ini sejalan dengan penelitian yang dilakukan oleh Yanti ${ }^{13}$ di Puskesmas Pringsewu Lampung yang mendapatkan responden yang memiliki status ekonomi tinggi dan mengalami anemia kehamilan sebanyak 40 orang $(48,8 \%)$ sedangkan yang memiliki status ekonomi rendah dan mengalami anemia kehamilan sebanyak 68 orang $(79,1 \%)$ dengan nilai $P=0,000$, yang menunjukkan bahwa terdapat hubungan antara status pekerjaan atau ekonomi dengan kejadian anemia pada ibu hamil. ${ }^{13}$

\section{Hubungan antara kadar Hd dan status pendidikan responden}

Hasil analisis hubungan kadar hemoglobin dengan pendidikan responden ini sejalan dengan penelitian oleh Sulastri yang menyatakan terdapat hubungan yang sangat bermakna antara pendidikan ibu dan kejadian anemia pada ibu hamil di Puskesmas Anggut Atas Kota Bengkulu. Hal ini didukung oleh hasil penelitian Puspaningrum yang melaporkan bahwa terdapat hubungan bermakna antara pendidikan ibu dan kadar $\mathrm{Hb}$ ibu hamil trimester III di RB Bhakti Ibu Kota Semarang. ${ }^{13}$

\section{Hubungan antara kadar $\mathrm{Hb}$ dan pendapatan keluarga responden}

Hasil penelitian terhadap kadar hemoglobin dan penghasilan kelurga berdasar- 
kan UMP menunjukkan terdapat hubungan bermakna yang tidak sejalan dengan penelitian yang dilakukan oleh Istiqomah yang menyatakan bahwa tidak terdapat hubungan antara pendapatan keluarga dan kejadian anemia di Surakarta. Hal tersebut dapat terjadi karena ibu dengan pendapatan tinggi dan selalu membeli makanan yang mahal belum tentu memperhatikan kandungan zat gizi dalam makanan tersebut. Sebagian besar penghasilan keluarga ibu hamil di wilayah kerja Puskesmas Mopuya ialah di bawah UMP $(<$ Rp. 2.500 .000 per bulan) yaitu sebanyak 49 dari 66 responden, dan yang dengan penghasilan $\geq R p$. 2.500.000 sebanyak 7 dari 66 responden . Responden yang menderita anemia kehamilan sebanyak 56 dari 66 ibu hamil. Dapat disimpulkan bahwa pendapatan atau status ekonomi keluarga dapat memengaruhi kejadian anemia pada ibu hamil. ${ }^{13}$

\section{Hubungan antara kadar $\mathrm{Hb}$ dan pola konsumsi makanan}

Hasil penelitian terhadap 86 jenis makanan dalam Food Frequency Questionnaire (FFQ) menunjukkan bahwa beras merupakan bahan makanan sumber karbohidrat yang paling sering dan paling banyak dikonsumsi ibu hamil di Bolaang mongondow, yaitu berjumlah $678,41 \mathrm{gr} /$ hari, sedangkan daging dengan jumlah konsumsi yang sering yaitu 42 orang dan telur dengan konsumsi sering yaitu 49 orang. Hasil ini menunjukan bahwa ibu hamil di Bolaang Mongondow yang mengonsumsi daging dan telur memiliki $\mathrm{Hb}>11 \mathrm{~g} / \mathrm{dl}$ yang menunjukkan konsumsi bahan makanan mengandung zat besi seperti pada penelitian ini berpengaruh juga terhadap kadar hemoglobin ibu hamil. Hasil penelitian ini sejalan dengan penelitian yang dilakukan oleh Anggraini yang menyatakan kecukupan zat besi pada ibu hamil sangat dibutuhkan untuk memasok pertumbuhan janin dan plasenta serta meningkatkan jumlah sel darah ibu. ${ }^{13}$

\section{SIMPULAN}

Dari hasil penelitian ini dapat disimpulkan bahwa terdapat hubungan bermakna antara kadar hemoglobin dengan usia ibu hamil, usia kehamilan, paritas, jarak kehamilan ukuran LILA, status pekerjaan, pendidikan ibu, pendapatan keluarga, serta pola konsumsi makan kacang-kacangan, daging dan telur. Tidak terdapat hubungan antara kadar hemoglobin dan pola konsumsi makanan ikan.

\section{DAFTAR PUSTAKA}

\section{Black RE, Aldeiman H, Buha ZA, Gillespil} S, Haddad L, Horton S, et al (Maternal and Child Nutrition Study Group). Maternal and Child Nutrition; building momentum for impact. Lancet. 2013;382(9890):372.

2. Ani LS. Anemia Defisiensi Besi. Jakarta: ECG, 2013; p. 2-3.

3. Susiloningtyas. Pemberian Zat Besi $(\mathrm{Fe})$ dalam Kehamilan [Skripsi]. Jakarta: FIK Unnisula; 2013.

4. Sudikno S. Prevalensi dan faktor risiko anemia pada wanita usia subur di rumah tangga miskin di Kabupaten Tasikmalaya dan Ciamis Provinsi Jawa Barat. Jurnal Kesehatan. 2016;7(2):71-82.

5. Branca F, Mahy L, Mustafa TS. The lack of progress in reducing anemia among women: the inconvenient truth. Bull World Health Organization. 2014;92:231.

6. Aminin F, Atika Wulandari A, Pratidina RL. Pengaruh kekurangan energy kronis dengan kejadian anemia pada ibu hamil. Jurnal Poltekkes Tanjungkarang. 2014; 5(2):167-72.

7. Tazkiah M, Umbul CW, Martini S. Determinan epidemiologi kejadian BBLR pada daerah endemis malaria di Kabupaten Banjar Provinsi Kalimantan Selatan [Tesis]. Surabaya: Universitas Airlangga; 2013.

8. Erlina R, Larasati TA, Kurniawan B. Faktor-faktor yang mempengaruhi ibu hamil terhadap kunjungan pemeriksaan kehamilan di Puskesmas Rawat Inap Panjang Bandar Lampung. Medical Journal of Lampung University. 2013;2(4):31.

9. Nurhayati N. Hubungan anemia dan karakteristik ibu hamil di Puskesmas Alianyang Pontianak [Skripsi]. Pontianak: Universitas Tanjungpura; 2011.

10. Anggraini M. Hubungan pola konsumsi 
pangan dengan kadar hemoglobin pada ibu hamil trimester ketiga di wilayah kerja Puskesmas Desa Lalang Kecamatan Medan Sunggal Tahun 2013 [Skripsi]. Medan: Universitas Sumatra Utara; 2013.

11. Budiman, Riyanto A, Juhaeriah J. Faktor ibu yang berhubungan dengan berat badan bayi lahir di Puskesmas Garuda tahun 2010. Jurnal Kesehatan Kartika $2011 ; 5(3)$.
12. Trihardiani I. Faktor risiko kejadian berat badan lahir rendah di wilayah kerja Puskesmas Singkawang Timur Utara [Skripsi]. Semarang: Universitas Diponegoro; 2011.

13. Yanti DAM, Sulistianingsih A, Keisnawati. Faktor-faktor terjadinya anemia pada ibu primigravida di wilayah kerja Puskesmas Pringsewu Lampung. Jurnal Keperawatan. 2015;6(2):3-4. 